\title{
Review of celiac disease presentation in a pediatric tertiary centre
}

\author{
Gracinda Nogueira OLIVEIRA ${ }^{1}$, Rajiv MOHAN ${ }^{2}$ and Andrew FAGBEMI ${ }^{2}$
}

Received 10/7/2017 Accepted 9/10/2017

\begin{abstract}
Background - Celiac disease is an immune-mediated disorder with a multiform presentation and therefore a challenging diagnosis. Objective - Our purpose is to identify the epidemiological, clinical, laboratory and histologic characteristics of children with celiac disease at diagnosis and on follow-up. Methods - Children with previously established or newly diagnosed celiac disease, admitted in a tertiary centre in a two-year period (2014-2016) were recruited. Data was collected retrospectively from electronic medical records and clinical notes, and subsequently analysed with SPSS version 20.0. Results - A total of 159 patients, out of 312, were included. Age ranged from 1 to 17 years (mean \pm SD: $8.5 \pm 4.5$ years, $69 \%$ girls). Disease presentation was classical in 60\%, non-classical in 25\%, subclinical in $10 \%$ and $5 \%$ classified as potential celiac disease. Non-classical and subclinical profiles had a higher mean age at presentation but not statistically significant ( $P$-value 0.24$)$. The most frequent gastrointestinal features at presentation were abdominal pain (58\%), diarrhea (43\%) and bloating $(27 \%)$. A positive family history for celiac disease was present in $24 \%(\mathrm{n}=35)$. We found anaemia in $23 \%$, low ferritin in $63 \%$ and a moderate to severe deficiency of 25 -hydroxyvitamin D in $62 \%$. celiac disease -specific serologic testing and esophagogastroduodenoscopy were performed in 99\%. Histology revealed modified Marsh 2 or 3 enteropathy in $94 \%$, the remaining had normal histology but positive human leukocyte antigen typing. Clinical improvement at 12 months of gluten-free diet was complete in $51 \%$ and partial in 49\%. IgA tTG normalized after 12-30 months of gluten-free diet in 45\%. On growth assessment at diagnosis and after 12-28 months of gluten-free diet, $100 \%$ had height increase (mean \pm SD: $7.11 \pm 4.43 \mathrm{~cm}$ ) and $96 \%$ weight gain (mean \pm SD: $5.60 \pm 4.91 \mathrm{~kg}$ ). Conclusion - Our findings outline the diverse clinical presentations of pediatric celiac disease that should be considered irrespective of age. Increased clinician's awareness will enable an early diagnosis and treatment, with subsequent symptom and nutritional status improvement.
\end{abstract}

HEADINGS - Celiac disease, diagnosis. Child. Serologic tests.

\section{INTRODUCTION}

Celiac disease $(\mathrm{CD})$ is a chronic small intestine immune-mediated disorder elicited by the ingestion of gluten in genetically predisposed individuals. In the United States and in Europe, the prevalence ranges from 1:300 to $1: 500^{(1)}$, and in UK is estimated to be 1:100 (2). The universal screening is not currently being advised. However, awareness should be raised and there should be a low threshold for investigating both symptomatic children and those with associated conditions, as it is known that approximately $90 \%$ of cases remain undiagnosed $^{(2)}$. The $\mathrm{CD}$ is commonly detected in patients with diarrhea, but the clinical manifestations of $\mathrm{CD}$ are numerous and vary from none (asymptomatic) to a broad spectrum of gastrointestinal symptoms and extraintestinal manifestations. These different modes of presentation, lead experts to elaborate the Oslo Classification ${ }^{(3)}$, which subdivides $\mathrm{CD}$ into symptomatic $\mathrm{CD}$, includes the "classical" and "non-classical" presentations, versus the "asymptomatic" or "subclinical" $\mathrm{CD}$. The classic $\mathrm{CD}$ presents with signs and symptoms of malabsorption and the non-classic $\mathrm{CD}$ is characterized by other gastrointestinal symptoms apart from diarrhea and extra-intestinal symptoms. The subclinical $\mathrm{CD}$ is below the threshold of clinical detection. There is also the "potential CD" describing the patients at risk of developing the disease in the future.

In this study, we retrospectively examined the clinical presenta- tion of $\mathrm{CD}$ pediatric patients admitted to a tertiary medical centre in the last two years with the diagnosis of $\mathrm{CD}$. Our main goal is to identify the epidemiological characteristics and clinical phenotype of these patients at presentation, as well as, the serology and histopathology findings. Furthermore, we aimed to define the clinical and serologic response to gluten-free diet (GFD) on follow-up.

\section{METHODS}

This retrospective study assessed all the pediatric patients admitted to a tertiary medical centre (Royal Manchester Children's Hospital, Manchester, United Kingdom) from April 2014 to April 2016, with the ICD-10 diagnosis code of Celiac disease (K90.0). Patients with repeated admissions, diagnosis in another hospital, more than 18 years or an unconfirmed diagnosis were excluded. Data from each selected patient was obtained retrospectively from medical records and included: demographic characteristics, symptoms, associated diseases, type of clinical presentation, family history, serology tests requested at presentation and their results, reason for testing if subclinical $\mathrm{CD}$, histopathology findings, human leukocyte antigen (HLA) testing, referral to a dietician and the clini$\mathrm{cal}$, serologic and growth response after at least 12 months of GFD.

The diagnosis relied mainly on duodenal biopsy and serology, and genetic testing with HLA typing would be performed when 
indicated. Histological findings in small intestine biopsies, taken from the bulb or the second duodenal portion, were classified according to the Modified Marsh Classification by Oberhuber ${ }^{(4)}$. Serology included mainly immunoglobulin A tissue transglutaminase antibodies (IgA tTG) as the first option, immunoglobulin A anti-endomysial antibodies (IgA EMA) if the first was weakly positive or not available and immunoglobulin $\mathrm{G}$ tissue transglutaminase antibodies (IgG tTG), immunoglobulin $\mathrm{G}$ anti-endomysial antibodies (IgG EMA) or immunoglobulin $\mathrm{G}$ anti-gliadin antibodies (IgG AGA) in the case of $\operatorname{IgA}$ deficiency ${ }^{(5)}$. The histopathology findings of crypt hyperplasia (lesion type 2) with villous atrophy (includes partial - type 3a, subtotal - type $3 \mathrm{~b}$ and total atrophy - type 3c), associated or not with a positive serology, confirmed the diagnosis of CD. Additionally, according to the European Society for Pediatric Gastroenterology Hepatology and Nutrition (ESPGHAN) guideline for the diagnosis of $\mathrm{CD}^{(6)}$, in cases with IgA tTG levels at least 10 times higher the upper reference limit along with positivity for EMA antibodies and HLA testing would also confirm the diagnosis. On the other hand, cases with positive serology and normal or mild duodenal lesions (increased intra-epithelial lymphocytes - lesion type 1) would be classified as potential CD if HLA testing was positive.

Regarding the clinical phenotype, according to the Oslo Classification, patients were divided in: 1) classical CD with a malabsorptive syndrome, presenting with diarrhea, steatorrhea, weight loss or growth failure as a requirement; 2) non-classical CD presents with gastrointestinal symptoms (except for diarrhea or steatorrhea) and extraintestinal manifestations; 3) subclinical CD for asymptomatic cases or with symptoms considered to be below the threshold for detection; 4) potential CD for patients with a normal intestinal mucosa who are at increased risk of developing $C D$ as indicated by a positive serology ${ }^{(3)}$. In this study in particular, we classified the patient as potential CD, only if, additionally, the HLA DQ2 and/ or HLA DQ8 tested positive.

\section{Statistical analysis}

Data collection and all the statistical analysis were performed on SPSS Statistics version 20.0 for Macintosh (Armonk, NY: IBM Corp.), using absolute and relative frequencies for categorical variables, means and standard deviation (SD) for continuous variables, ANOVA test for variance analysis and Fisher's exact tests were used to compare independent data. A significance level of $P<0.05$ was considered.

\section{RESULTS}

One hundred and fifty-nine patients out of the three hundred and twelve initially elected were included (FIGURE 1). The mean age at diagnosis was $8.5 \pm 4.5$ years (range 1.1 to 17.7 years) and $69 \%$ were females. Eleven patients $(6.9 \%)$ were less than 2 years of age (FIGURE 2). Family history ( $n=147)$ was positive for CD in $24 \%$ (TABLE 1). Mean age and standard deviation $\left(\mathrm{x}^{-} \pm \mathrm{SD}\right)$ values at presentation were calculated for the four types of CD (FIGURE 3). The classical presentation occurred in $59.7 \%$, non-classical in $25.2 \%$, subclinical in $10.1 \%$ and potential $\mathrm{CD}$ in $5.0 \%$, as shown on TABLE 2. On comparison, subclinical and non-classical groups had a higher mean age at presentation, but not statiscally significant on ANOVA test ( $P$-value 0.24$)$. The box plot shows how all the groups overlap and explains the absence of age-specific differences with respect to clinical presentation (FIGURE 3).

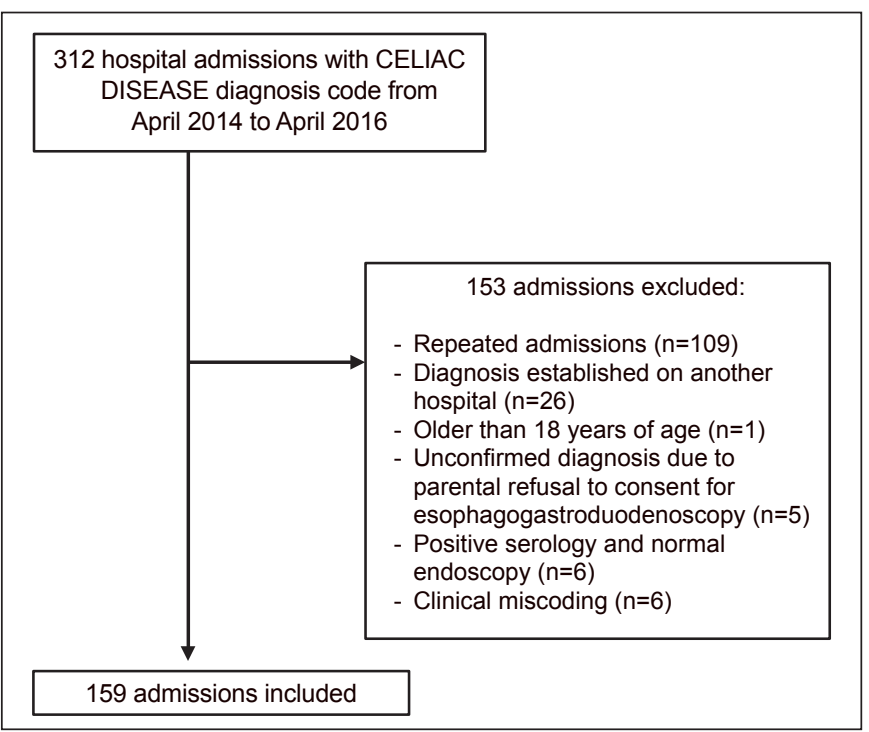

FIGURE 1. Flowchart of the selection process.

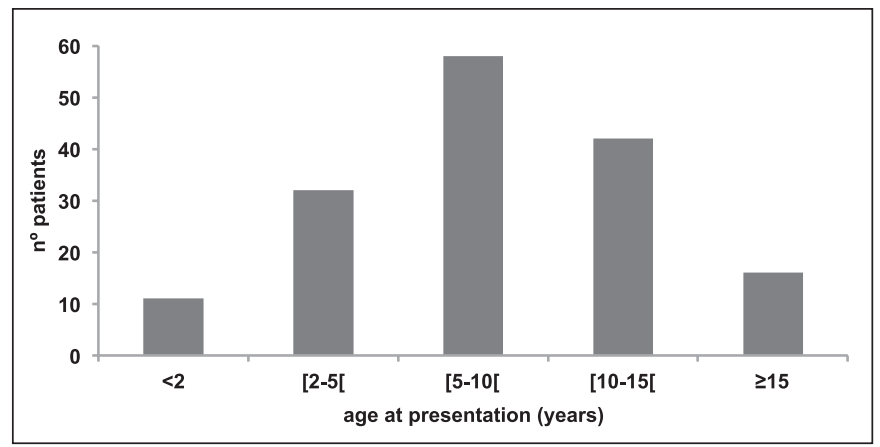

FIGURE 2. This image represents the age at presentation of celiac disease in the 159 subjects. Infants less than 2 years of age represented only $6.9 \%$ of the population. $20.1 \%$ of subjects were aged between 2 and 5 years, $36.5 \%$ between 5 and 10 years, $26.4 \%$ between 10 and 15 years and $10.1 \%$ were more than 15 years.

TABLE 1. Demographic characteristics of patients at presentation $(\mathrm{n}=159)$

\begin{tabular}{lc}
\hline Variables & $\begin{array}{c}\text { Patients } \\
\mathrm{n}=159(\%)\end{array}$ \\
\hline Mean $\lceil \pm$ SD $]$ age in years (range) & $8.5 \pm 4.5(1.1-17.7)$ \\
Gender & $50(31.4)$ \\
Male & $109(68.6)$ \\
Female & $\mathrm{n}=147(\%)$ \\
& $44(29.9)$ \\
Positive family history & $35923.8)$ \\
Positive for CD & $11(6.9)$ \\
1st degree & $24(15.0)$ \\
Other & $4(2.7)$ \\
Positive for IBD & $2(1.4)$ \\
1st degree & $2(1.4)$ \\
Other & $5(3.4)$ \\
Positive for IBS & $2(1.4)$ \\
1st degree & $3(2.0)$ \\
Other & $103(70.1)$ \\
Negative family history & $12(7.5)$ \\
Unknown family history &
\end{tabular}

CD: celiac disease; IBD: inflammatory bowel disease. 


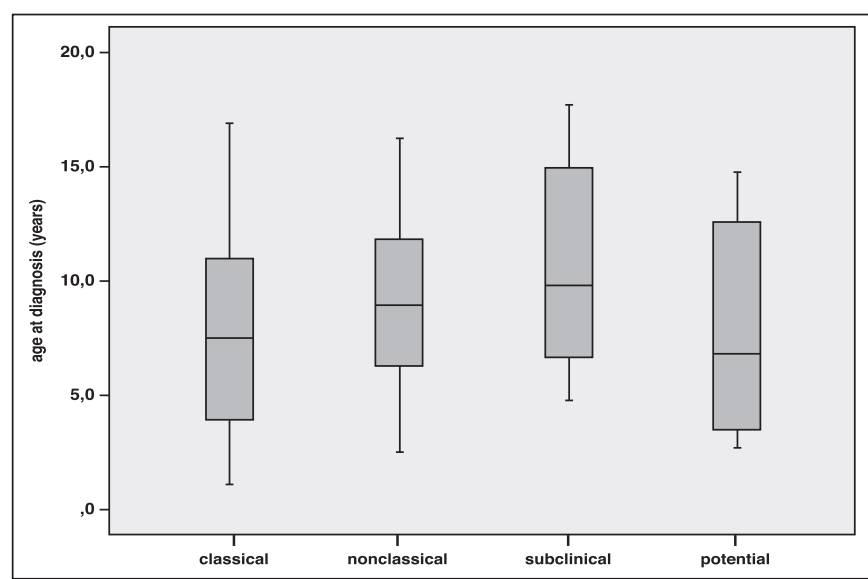

FIGURE 3. The box-plot representation shows the age distribution in years for each clinical profile, with mean and standard deviation $\left(\bar{x}_{ \pm} S D\right)$, median ( $\mathrm{M})$ and range ( $\mathrm{R}$, minimum-maximum). The bold line is the median value, the lower and upper limits of each box represent the first and third quartiles, respectively and whiskers represent the limits of extreme measurements. Classical profile: $\bar{x}_{ \pm} \mathrm{SD} 7.87 \pm 4.47$ years, $\mathrm{M} 7.52$ years, $\mathrm{R}$ 1.07-16.91 years. Non-classical profile: $\overline{\mathrm{x}} \pm$ SD $9.17 \pm 4.08$ years, $\mathrm{M} 8.91$ years, R 2.49-16.27 years. Subclinical profile: $\bar{x}_{ \pm}$SD $10.85 \pm 4.50$ years, $M$ 9.80 years, $R$ 4.77-17.68 years. Potential profile: $\bar{x} \pm S D$ 7.88 \pm 5.13 years, M 6.80 years, R 2.66-14.72 years.

TABLE 2. Symptoms and clinical profile of patients at presentation $(n=159)$

\begin{tabular}{lc}
\hline Variables & $\begin{array}{c}\text { Patients } \\
\mathrm{n}=159(\%)\end{array}$ \\
\hline Asymptomatic & $16(10.1)$ \\
Symptomatic & $143(89.9)$ \\
Symptoms & $\mathrm{n}=143(\%)$ \\
Gastrointestinal & \\
Abdominal pain & $92(64.3)$ \\
Diarrhea & $69(48.3)$ \\
Bloating & $43(30.1)$ \\
Constipation & $37(25.9)$ \\
Vomiting & $28(19.6)$ \\
Nausea & $18(12.6)$ \\
Blood in stools & $9(6.3)$ \\
Flatulence & $7(4.9)$ \\
Mucous in stools & $6(4.2)$ \\
Mouth ulcers & $4(2.8)$ \\
Heartburn & $3(2.1)$ \\
Extraintestinal & \\
Weight loss & $46(32.2)$ \\
Failure to thrive & $32(22.4)$ \\
Lethargy & $32(22.4)$ \\
Anorexia & $27(18.9)$ \\
Irritability & $11(7.7)$ \\
Puberty delay & $4(2.8)$ \\
Hair loss & $3(2.1)$ \\
Arthritis, arthralgia & $3(2.1)$ \\
Muscle wasting & $2(1.4)$ \\
Clinical profile & $\mathrm{n}=159(\%)$ \\
Classical & $95(59.7)$ \\
Non-classical & $40(25.2)$ \\
Potential & $16(10.1)$ \\
\hline & $8(5.0)$ \\
\hline
\end{tabular}

One hundred and forty three children $(n=143)$ presented with symptoms and $59 \%$ had 3 or more presenting symptoms. The remaining sixteen subclinical cases were asymptomatic and half presented with unexplained anemia and/or ferritin deficiency. Abdominal pain $(64.3 \%)$ was the most common reported symptom at presentation (TABLE 2), followed by diarrhea (48.3\%), bloating (30.1\%), constipation $(25.9 \%)$, weight loss $(32.2 \%)$, failure to thrive and lethargy (22.4\% each). Less frequently reported gastrointestinal symptoms were vomiting $(19.6 \%)$, nausea $(12.6 \%)$ and feces with blood or mucous $(10.5 \%)$. Less common extra-intestinal symptoms included anorexia $(18.9 \%)$ and irritability $(7.7 \%)$. Out of the symptomatic children, 44 were aged less than five (preschool) and 99 had five years or greater. TABLE 3 displays the number of subjects with each symptom and the numbers in brackets describe the percentage of the age group with that symptom. The most common presenting symptoms in younger children $(<5$ years) were diarrhea $(63.6 \%)$ and bloating $(59.1 \%)$, yielding both a significant difference in Fisher's exact test $(P<0.05)$. In older children ( $\geq 5$ years), also with a statistically significant association, the most common presenting feature was abdominal pain $(75.8 \%)$.

TABLE 3. Comparison of Clinical features in two age groups $(n=143)$

\begin{tabular}{|c|c|c|c|c|}
\hline Variables & $\begin{array}{c}\text { Age } \\
<5 \text { years } \\
n=44 \\
(\% \text { of group) }\end{array}$ & $\begin{array}{c}\text { Age } \\
\geq 5 \text { years } \\
n=99 \\
\text { (\% of group) }\end{array}$ & $P$-value* & OR $(95 \% \mathrm{CI})^{\#}$ \\
\hline $\begin{array}{l}\text { Abdominal } \\
\text { pain }\end{array}$ & $\mathrm{n}=17(38.6)$ & $\mathrm{n}=75(75.8) *$ & $<0.001$ & $5.0(2.3-10.6)$ \\
\hline Bloating & $\mathrm{n}=26(59.1)$ & $\mathrm{n}=17(17.2)^{*}$ & $<0.001$ & $1.4(0.07-0.3)$ \\
\hline Nausea & $\mathrm{n}=1(2.3)$ & $\mathrm{n}=17(17.2)^{*}$ & 0.01 & $8.9(1.1-69.3)$ \\
\hline Vomiting & $\mathrm{n}=10$ & $\mathrm{n}=18(18.2)$ & 0.65 & $0.8(0.3-1.8)$ \\
\hline Diarrhea & $\mathrm{n}=28(63.6)$ & $\mathrm{n}=41(41.4)^{*}$ & 0.02 & $0.4(0.2-0.8)$ \\
\hline Constipation & $\mathrm{n}=10$ & $\mathrm{n}=27(27.3)$ & 0.68 & $1.3(0.6-2.9)$ \\
\hline $\begin{array}{l}\text { Failure to } \\
\text { thrive }\end{array}$ & $\mathrm{n}=10$ & $\mathrm{n}=22(22.2)$ & 1.00 & $1.0(0.4-2.3)$ \\
\hline Weight loss & $\mathrm{n}=17$ & $\mathrm{n}=29(29.3)$ & 0.33 & $0.7(0.3-1.4)$ \\
\hline Anorexia & $\mathrm{n}=10$ & $\mathrm{n}=17(17.2)$ & 0.49 & $0.7(0.3-1.7)$ \\
\hline Lethargy & $\mathrm{n}=7(15.9)$ & $\mathrm{n}=25$ & 0.28 & $1.8(0.7-4.5)$ \\
\hline Irritability & $\mathrm{n}=3(6.8)$ & $\mathrm{n}=8(8.1)$ & 1.00 & $1.2(0.3-4.8)$ \\
\hline
\end{tabular}

*Established significance level: P-value $<0.05$. "Estimated Odds Ratio and associated 95\% confidence intervals. 
At the time of CD diagnosis, we identified several associated conditions, as shown in TABLE 4. Type 1 diabetes mellitus (T1D, $9.4 \%$ ) was the leading immunological disorder, followed by IgA deficiency $(5.0 \%)$ and hypothyroidism $(4.4 \%)$. T1D occurred first in $88 \%$ of the 16 patients with both CD and T1D diagnosis. Atopy

TABLE 4. Related diagnosis at presentation $(n=159)$

\begin{tabular}{|c|c|}
\hline Diagnosis & $\begin{array}{c}\text { Patients } \\
\mathrm{n}=159(\%)\end{array}$ \\
\hline Haematological and Immunological disorders & $67(42.1)$ \\
\hline Anaemia & $37(23.3)$ \\
\hline Type 1 diabetes mellitus & $15(9.4)$ \\
\hline IgA deficiency & $8(5.0)$ \\
\hline Hypothyroidism & $7(4.4)$ \\
\hline Atopic disorders & $43(27.0)$ \\
\hline Allergic asthma & $19(11.9)$ \\
\hline Atopic eczema & $14(8.8)$ \\
\hline Cow's milk protein allergy & $4(2.5)$ \\
\hline Other food allergies & $3(1.9)$ \\
\hline Urticaria & $2(1.3)$ \\
\hline Allergic rhinitis & $1(0.6)$ \\
\hline Neurodevelopmental disorders & $13(8.2)$ \\
\hline Neurodevelopmental delay & $8(5.0)$ \\
\hline Autism & $3(1.9)$ \\
\hline Asperger & $1(0.6)$ \\
\hline ADHD & $1(0.6)$ \\
\hline Rheumatological and connective tissue disorders & $12(7.5)$ \\
\hline Joint hypermobility syndrome & $5(3.1)$ \\
\hline Juvenile idiopathic arthritis & $4(2.5)$ \\
\hline Mixed connective-tissue disease & $1(0.6)$ \\
\hline Osteogenesis imperfecta and osteopenia & $1(0.6)$ \\
\hline Achilles tendinitis and plantar fasciitis & $1(0.6)$ \\
\hline Neurological disorders & $8(5.0)$ \\
\hline Migraine & $5(3.1)$ \\
\hline Cerebral palsy & $2(1.3)$ \\
\hline Epilepsy & $1(0.6)$ \\
\hline Psychological disorders & $7(4.4)$ \\
\hline Anxiety & $4(2.5)$ \\
\hline Mood swings & $2(1.3)$ \\
\hline Pica eating disorder & $1(0.6)$ \\
\hline Syndromes & $7(4.4)$ \\
\hline Joubert & $2(1.3)$ \\
\hline Down & $1(0.6)$ \\
\hline Turner & $1(0.6)$ \\
\hline Hallermann-Strieff & $1(0.6)$ \\
\hline Crouzon & $1(0.6)$ \\
\hline $18 \mathrm{q}$ deletion & $1(0.6)$ \\
\hline Other gastrointestinal disorders & $6(3.8)$ \\
\hline Eosinophilic esophagitis & $3(1.9)$ \\
\hline Crohn's disease & $2(1.3)$ \\
\hline Indeterminate colitis & $1(0.6)$ \\
\hline Dental enamel defects & $4(2.5)$ \\
\hline Skin disorders & $3(1.9)$ \\
\hline Psoriasis & $1(0.6)$ \\
\hline Dermatitis herpetiformis & $1(0.6)$ \\
\hline Erythema nodosum & $1(0.6)$ \\
\hline
\end{tabular}

ADHD: attention deficit hyperactivity disorder.
$(27 \%)$ was a common finding. Thirteen patients had neurodevelopment disorders (8.2\%). Migraine (3.1\%) was the main neurological condition and anxiety $(2.5 \%)$ the most common psychological disorder. Rheumatological and connective tissue conditions affected twelve patients, $3.1 \%$ had joint hypermobility syndrome and $2.5 \%$ juvenile idiopathic arthritis. Seven patients had a genetic syndrome. Eosinophilic esophagitis $(1.9 \%)$ was the main associated gastrointestinal disorder.

Serological testing and duodenal biopsy were both performed in $99.4 \%$ of patients (TABLE 5). IgA tTG was the most frequently requested serological testing (86.7\%). We had access to 132 esophagogastroduodenoscopy (EGD) reports; of which 73\% had a modified Marsh enteropathy type 3, 5.7\% type 2 and 5.1\% had no findings (potential CD patients). Six out of the 14 cases with HLA typing were both HLA DQ2/DQ8 positive. All potential CD patients had a positive genetic testing.

TABLE 5. Serological tests, histopathological findings and HLA typing

\begin{tabular}{lc}
\hline Diagnosis & Patients $\mathrm{n}=159(\%)$ \\
\hline Serologic testing performed & $158(99.4)$ \\
Seropositive & $154(97.4)$ \\
IgA tTG $[>6.9 \mathrm{U} / \mathrm{mL}]$ & $137(86.7)$ \\
IgA EMA + & $44(27.8)$ \\
IgG tTG + & $8(5.1)$ \\
IgG AGA + & $8(5.1)$ \\
IgA AGA + & $8(5.1)$ \\
Seronegative* & $4(2.5)$ \\
Serologic testing not performed & $1(0.6)$ \\
Duodenal biopsy (modified Marsh) & $158(99.4)$ \\
0 & $8(5.1)$ \\
1 & $0(0.0)$ \\
2 & $9(5.7)$ \\
3 (a, b, c) & $115(73)$ \\
Unknown & $26(16.5)$ \\
OGD not performed & $1(0.6)$ \\
HLA Typing & $14(8.8)$ \\
HLA DQ2/8+ & $6(42.9)$ \\
HLA DQ2+ & $6(42.9)$ \\
HLA DQ8+ & $2(14.3)$ \\
\hline
\end{tabular}

* Seronegative but with no immunodeficiency. ${ }^{*}$ Incidental diagnosis in a patient with inflammatory bowel disease. ${ }^{\bullet} \mathrm{IgA}$ tTG titre > 10 times upper limit of normal and positive HLA typing.

Routine blood tests showed anaemia in $23.3 \%$ (TABLE 6). The 25-hydroxyvitamin $\mathrm{D}$ analysis $(\mathrm{n}=55)$ revealed a moderate to severe deficiency in $62 \%$ and ferritin levels $(n=75)$ were low in $63 \%$. At 12 months of GFD ( $n=75), 51 \%$ reported a complete resolution of symptoms, $49 \%$ partial improvement and none of them mentioned no improvement or worsening of symptoms. In terms of serological response $(n=42)$, we compared IgA tTG levels at diagnosis and after 12 to 30 months $(15.57 \pm 4.53)$ on GFD and observed that the antibody titre normalized in $45 \%$ $(<6.9 \mathrm{U} / \mathrm{mL})$, decreased half or more in $40.5 \%$, increased in two cases and had no change in three cases. The last five cases had a very poor compliance documented. 
TABLE 6. Haemoglobin, Ferritin and 25-hydroxyvitamin D (D2+D3) levels at presentation

\begin{tabular}{lcc}
\hline Variables & Patients $\mathrm{n}(\%)$ & Reference values \\
\hline Haemoglobin & $\mathrm{n}=159(100)$ & \\
Adequate & $122(76.7)$ & $11.5-16.5 \mathrm{~g} / \mathrm{dL}$ \\
Anaemia & $37(23.3)$ & $<11.5 \mathrm{~g} / \mathrm{dL}$ \\
25-hydroxyvitamin D & $\mathrm{n}=55(34.6)$ & \\
Adequate & $21(38.2)$ & $>50 \mathrm{nmol} / \mathrm{L}$ \\
Moderate deficiency & $25(45.5)$ & $25-50 \mathrm{nmol} / \mathrm{L}$ \\
Severe deficiency & $9(16.4)$ & $<25 \mathrm{nmol} / \mathrm{L}$ \\
Ferritin & $\mathrm{n}=75(47.2)$ & \\
Adequate & $28(37.3)$ & $15-200 \mu \mathrm{G} / \mathrm{L}$ \\
Lower-than-normal & $47(62.7)$ & $<15 \mu \mathrm{G} / \mathrm{L}$ \\
\hline
\end{tabular}

On growth assessment $(\mathrm{n}=57)$, at presentation and after 12-28 months on GFD (15.49 \pm 4.32$), 100 \%$ thrived with a mean height increase of $7.11 \pm 4.43 \mathrm{~cm}$ and $96 \%$ gained weight, a mean of $5.60 \pm 4.91 \mathrm{~kg}$. All the 159 patients were referred to a nutritionist.

\section{DISCUSSION}

The children included in this retrospective review presented with a wide variety of clinical features. Abdominal pain and diarrhea were the most common gastrointestinal symptoms at presentation and weight loss followed by failure to thrive were, not surprisingly, the main extra-intestinal findings. We found an increased prevalence of $\mathrm{CD}$ amongst females compared to males, in accordance with results in the literature ${ }^{(7)}$.

Considering that the variable clinical picture of $\mathrm{CD}$ is related to both genetical and immunological bases, the age of onset may influence the clinical manifestation of the disease. We found a higher mean age at presentation on the subclinical and non-classical groups and, though it was not statistically significant, it could be associated to a delay in the recognition of the silent and atypical cases. According to the results of Bardella et al., the prevalence of the non-classic CD presentation increased with age, from $10.7 \%$ in children with less than 2 years, to $28.2 \%$ if 2 to 14 years and to $61.1 \%$ in subjects more than 14 years $^{(8)}$.

The leading clinical manifestations of $\mathrm{CD}$ in younger children were diarrhea and bloating and older children more commonly presented with abdominal pain. Even though abdominal pain is a frequent symptom in older children with $\mathrm{CD}$, there is no association between classical recurrent abdominal pain and coeliac disease ${ }^{(9)}$.

All patients had a full blood count taken at the time of diagnosis and anemia was identified in $23 \%$ of the total. Anemia prevalence at disease presentation is high and comparable to available data, ranging from $9 \%-18 \% \%^{(10,11)}$. Unfortunately, only $47 \%$ of subjects in our study had blood taken for ferritin. Thus the true prevalence of iron deficiency in our population is uncertain. In half of our asymptomatic cases, the only clue for $\mathrm{CD}$ diagnosis was the persistent anemia and/or ferritin deficiency. A prospective study, from Howard et al., recorded a 5\% CD prevalence in a group of 333 children with iron and/or folate deficiency ${ }^{(12)}$.

Only one third of our patients had a 25-hydroxyvitamin D assessment at diagnosis and $62 \%$ of them had a moderate to severe deficiency. Vitamin D deficiency is common in children with newly diagnosed $\mathrm{CD}$, with a reported prevalence up to $27 \% \%^{(10,13,14)}$.
A recent retrospective study by Wessels et al., including 182 children, reported that micronutrient assessment is relevant at the time of $\mathrm{CD}$ diagnosis, but has little diagnostic yield during followup consultations once the patient is started on a GFD ${ }^{(10)}$.

The association between $\mathrm{CD}$ and autoimmune disorders is well known, due to shared pathological and genetical mechanisms. There is a possibility of genetic susceptibility to autoimmunity through IL-2 and IL-21 locus, both inside and outside de HLA region ${ }^{(7)}$. The prevalence of $\mathrm{CD}$ in children with T1D has been estimated at $15 \%{ }^{(15)}$. Time course-studies on the diagnosis of T1D and CD suggests that the diagnosis of T1D usually occurs first, followed by $\mathrm{CD}^{(16,17)}$. Our study reflects this tendency as T1D was diagnosed first in $88 \%$ of our patients with CD and T1D. In these patients, GFD might improve glycemic control and protect patients against development of diabetes-related vascular complications ${ }^{(18)}$. Overall, the reported prevalence of autoimmune thyroid impairment in pediatric patients with $\mathrm{CD}$ ranges from $20.4 \%$ to $41.1 \%{ }^{(19,20)}$ and its clinical course does not appear to be influenced by a gluten-free $\operatorname{diet}^{(21)}$. In most $\mathrm{CD}$ patients with autoimmune thyroiditis, the immune response against the target cell destroys the thyroid gland gradually, leading to hypofunction. The prevalence of hypothyroidism in our patients $(4.4 \%)$ is similar to the one obtained by Ansaldo et al. $(4.7 \%)^{(22)}$.

It has been shown that atopy is found in coeliac patients, but it is still unclear whether this coexistence is to be considered coincidental or an expression of a real association. Several case-control studies ${ }^{(23,24)}$ failed to demonstrate an increased prevalence of atopic conditions in children with $\mathrm{CD}$ when compared to controls. On the other hand, Kero et al. ${ }^{(25)}$ reported a cumulative incidence of asthma in children with $\mathrm{CD}(24.6 \%)$ significantly higher than in children without $\mathrm{CD}(3.4 \% ; P<0.001)$ and Ress et al. ${ }^{(26)}$ showed that $\mathrm{CD}$ prevalence in children with active atopic dermatitis was more than four times as high as in randomly selected children. Some studies have suggested that the association between $\mathrm{CD}$ (T-helper cell type 1 disease) and atopy (T-helper cell type 2 disease) may be the result of vitamin D deficiency and subsequently insufficient Treg-cell capacity and shared risk factors ${ }^{(27,28)}$.

Neurological disease and behavioral symptoms also appear to be common in children with $\mathrm{CD}$ and are occasionally the initial clinical manifestation. We found an autism spectrum disorder (ASD) prevalence of $2.5 \%$ in our series, comprising three patients with autism and one with Asperger syndrome. Our finding could be significant, considering that just a few case reports ${ }^{(29,30)}$ mention a direct association between autism and $\mathrm{CD}$, while case-control studies failed to do so ${ }^{(31,32)}$. Nevertheless, there are several studies that have found familial autoimmunity to be a risk factor for autism ${ }^{(33-36)}$. We also identified five children with migraine, four with anxiety and two with mood swings. In a study of children with newly diagnosed $\mathrm{CD}$, approximately $20 \%$ had subclinical neurological abnormalities such as peripheral polyneuropathy and cortical atrophy ${ }^{\left({ }^{(37)}\right.}$. A recent study showed that 3.5-year-old children with persistently positive tTG antibodies on a gluten-containing diet were more likely to manifest behavioral problems, including anxiety, depression and aggressiveness, when compared to those with negative antibody tests ${ }^{(38)}$. The pathogenesis of the neurologic symptoms is unclear but they tend to resolve on a GFD ${ }^{(39-41)}$.

The risk of having CD is increased in children with specific genetic disorders. We found a child with Down and another with Turner syndrome. The prevalence of CD ranges from $3.2 \%$ to $10.3 \%$ in children with Down syndrome ${ }^{(42-45)}$, from $2 \%$ to $10 \%$ in Turner syndrome ${ }^{(4)}$ and is estimated to be $9.5 \%$ in Williams-Beuren 
syndrome ${ }^{(47)}$. Additionally, we spotted two cases diagnosed with CD and Joubert Syndrome (JS), both with cerebellar ataxia and neurodevelopmental delay. CD (OMIM\# 212750) is associated with an increased susceptibility to cerebellar ataxia ${ }^{(48)}$, but an association with JS seems unlikely when we consider the different pathogenic mechanisms involved. In JS there is dysgenesis of the cerebellar vermis $^{(49)}$, while in CD an immune-mediated neurotoxicity has been proposed $^{(50,51)}$. To the best of our knowledge no study has previously described an association of CD with JS. Also, a correlation between three other identified syndromes, Hallermann-Strieff, Crouzon and $18 \mathrm{q}$ deletion, and CD was not found in the literature.

The association between eosinophilic esophagitis (EoE) and CD remains controversial, with studies yielding different results ${ }^{(52,53)}$. We found a prevalence of EoE of $1.9 \%$ in our case series, but a prevalence ranging from $3.2 \%$ to $10 \%$ has been described ${ }^{(52,54,55)}$. Thus in children with suspected CD undergoing EGD, obtaining routine esophageal biopsies might be advisable ${ }^{(52,54,55)}$. Also, the lack of validity of the currently available studies prevent us from unequivocally exclude this association ${ }^{(56)}$.

Three of our patients had an inflammatory bowel disease (IBD). Some reports have shown an association between CD and IBD ${ }^{(57-60)}$, but only a few pediatric studies are available. A case-control study by Virta et al. reported a higher frequency of CD $(2.2 \%)$ in a group of 595 children with IBD, when compared to the general population $(0.5-0.7 \%)^{(61)}$. However, a cohort by El-Matary et al., with a smaller population of 164 children with IBD, found no difference on CD prevalence when compared to the control group ${ }^{(62)}$. Thus, additional pediatric studies are needed to further clarify common pathways between these two immune-mediated diseases.

Apart from Sjogren's syndrome, research on CD-associated connective tissue disorders (CTD) is scarce and comprises mostly case-control studies or individual cases. The joint hypermobility syndrome (JHS), a commonly underdiagnosed heritable CTD possibly related to $\mathrm{CD}^{(63-65)}$, was present in $3.1 \%$ of our patients. The mixed connective-tissue disease (MCTD), an overlap of systemic lupus erythematosus (SLE), scleroderma and myositis, previously described in association to $\mathrm{CD}^{(66)}$, affected only one patient. Osteogenesis imperfecta $(\mathrm{OI})$, an autosomal dominant hereditary disease defined by bone frailty and CTD was present in one of our patients with generalized osteopenia. Although an association is not proven yet, the coexistence of OI and CD has been described ${ }^{(67)}$. Regardless, it is convenient to rule out the presence of $\mathrm{CD}$, as the clinical improvement on GFD might be considerable.

There are several studies on the association between CD and joint manifestations ${ }^{(68-70)}$, but only a few describe the connection to the inflammation involving the entheses (insertions of tendons and ligaments) ${ }^{(71-73)}$, which is an early feature of this process that is frequently missed during clinical evaluation. We found a case of Achilles tendinitis and plantar fasciitis that jointly comprise the enthesitis. The literature shows conflicting results on the impact of GFD, with some achieving a complete remission while others have no response ${ }^{(71,72)}$.

The juvenile idiopathic arthritis (JIA) encompasses different forms of chronic arthritis in children, all characterized by joint pain and inflammation ${ }^{(74)}$. We found four patients with CD and JIA, accounting for $2.5 \%$ of cases. The prevalence of JIA in children with $\mathrm{CD}$ is not clearly outlined. Conversely, the reported prevalence of $\mathrm{CD}$ in children presenting with JIA ranges between $2.5 \%$ and $6.6 \%{ }^{(75,76)}$.

There is strong evidence confirming an increased risk of dental enamel defects (DED) in children with CD and it may be the only presenting symptom ${ }^{(1,77)}$. The incisors and molars are the most frequently affected ${ }^{(77-79)}$. We report a $2.5 \%$ prevalence of DED, but three case-control studies have reported estimates of $55 \%, 62 \%$ and $73 \%$ (as compared with $18 \%, 21 \%$ and $0 \%$ in the corresponding control groups), indicating higher prevalence of DED among children with $\mathrm{CD}^{(77-79)}$. A significant improvement on GFD in children with DED and CD is reported, so screening for CD is highly recommended, particularly in the presence of hypocalcemia ${ }^{(78,80)}$.

Not surprisingly we found a case of dermatitis herpetiformis (DH), which is considered as the specific cutaneous expression of gluten intolerance and the most common skin manifestation of $\mathrm{CD}^{(81-83)}$. The suspicion of $\mathrm{DH}$ should prompt screening for $\mathrm{CD}$ and the first-line therapy is GFD ${ }^{(81,82)}$.

We have been able to find one case of psoriasis and one of erythema nodosum (EN). Several studies support an increased risk of psoriasis in patients with CD and report the positive impact of GFD on skin lesions ${ }^{(84,85)}$. However, this association remains controversial due to the few data currently available. Similarly, the available evidence supporting the association of $\mathrm{CD}$ with $\mathrm{EN}$ is very limited and based exclusively on single case reports in which patients become asymptomatic on a GFD ${ }^{(86,87)}$. We suggest that a serological evaluation for $\mathrm{CD}$ should be considered in patients with psoriasis and $\mathrm{EN}$, particularly in non-responders to first-line therapies.

Even though the current study retrospectively describes relevant data on English children with CD, we recognize its limitations. The selected children with CD attended a tertiary referral centre and this could result in a selection bias due to the fact that those patients probably have more severe disease and associated conditions. The large number of repeated admissions excluded from our study population $(n=109)$ were not considered or analyzed, since most patients were clinically stable and being admitted for multidisciplinary follow-up clinics. Also, the retrospective nature of this study explains the lack of availability of specific measures and data.

To conclude, we present a wide variety of celiac disease presentations and related conditions, some yet to be confirmed, so it should be noticed that further studies in the pediatric population with larger samples are needed to reliably corroborate identified associations and to clarify if the age at presentation is a determinant of clinical features in CD.

\section{CONCLUSION}

These findings outline the diverse clinical presentations of paediatric $\mathrm{CD}$ that should be considered irrespective of age. A classical symptom-based case finding is insufficient to identify a vast number of children with non-classic manifestations of $\mathrm{CD}$ who are likely to report to specialists other than gastroenterologists. The universal screening is not currently being advised, which emphasizes the importance of raising awareness amongst health care professionals to the different clinical presentations of the disease and the associated autoimmune conditions. A comprehensive approach to $\mathrm{CD}$ will enable an early recognition and treatment, with subsequent symptom relief and nutritional status optimization.

\section{Authors' contributions}

Oliveira GN performed study design, data collection, statistical analysis, manuscript writing and literature review; Mohan R participated in critical revision of the study; Fagbemi A has been involved in the conceiving and study design, analysis and interpretation of data, critical revision and final approval of the manuscript. 
Oliveira GN, Mohan R, Fagbemi A. Revisão da apresentação da doença celíaca num hospital pediátrico terciário. Arq Gastroenterol. 2018;55(1):86-93.

RESUMO - Contexto - A doença celíaca é uma doença imuno-mediada com uma apresentação multiforme constituindo, por isso, um desafio diagnóstico. Objetivo - O objetivo deste trabalho foi identificar as características epidemiológicas, clínicas, laboratoriais e histológicas ao diagnóstico e no seguimento de crianças com doença celíaca. Métodos - Foram incluídas crianças com doença celíaca admitidas num hospital pediátrico terciário ao longo de 2 anos (2014-2016). A recolha da informação clínica foi retrospetiva a partir dos processos clínicos eletrônicos ou em papel e analisada com o software SPSS versão 20.0. Resultados - Foram incluídos 159 doentes, a partir de uma amostra de 312. A idade variou entre 1 e 17 anos (média \pm desvio padrão: $8,5 \pm 4,5$ anos, $69 \%$ do sexo feminino). A apresentação da doença foi clássica em $60 \%$, não clássica em $25 \%$, subclínica em $10 \%$ e classificada como doença celíaca potencial em $5 \%$. Os doentes com apresentações não clássica e subclínica, tiveram uma idade média de apresentação superior, mas sem significância estatística $(P=0,24)$. Ao diagnóstico, as manifestações gastrointestinais mais frequentes foram dor abdominal (58\%), diarreia (43\%) e distensão abdominal (27\%). Havia história familiar de doença celíaca em $24 \%$ (n=35) dos doentes. Foi detetada anemia em $23 \%$, níveis baixos de ferritina em $63 \%$ e um défice moderado a grave de 25 -hidroxivitamina $\mathrm{D}$ em $62 \%$. Foram realizados testes serológicos para a doença celíaca e a esofagogastroduodenoscopia em $99 \%$. Os achados histológicos revelaram enteropatia nos estágios de Marsh modificado tipo 2 ou 3 em $94 \%$, os restantes apresentavam histologia normal mas tipagem do antigénio leucocitário humano positiva. Aos 12 meses de dieta sem glúten a melhoria clínica foi completa em 51\% e parcial em 49\%. O valor de IgA tTG normalizou em 45\% após 12-30 meses de dieta sem glúten. Na avaliação do crescimento, ao diagnóstico e após 12-28 meses de dieta sem glúten, $100 \%$ teve evolução estatural positiva (média \pm DP: $7,11 \pm 4,43 \mathrm{~cm}$ ) e $96 \%$ aumentaram de peso (média \pm DP: $5,60 \pm 4,91 \mathrm{~kg}$ ). Conclusão - Os resultados do estudo evidenciam a diversidade da apresentação clínica da doença celíaca em pediatria, devendo ser considerada em todas as idades. Um maior reconhecimento da doença pelos médicos permitirá um diagnóstico e tratamento atempados, com subsequente melhoria sintomática e do estado nutricional.

DESCRITORES - Doença celíaca, diagnóstico. Criança. Testes sorológicos.

\section{REFERENCES}

1. Hill ID, Dirks MH, Liptak GS, Colletti RB, Fasano A, Guandalini S, et al. Guideline for the diagnosis and treatment of celiac disease in children: recommendations of the North American Society for Pediatric Gastroenterology, Hepatology and Nutrition. J Pediatr Gastroenterol Nutr. 2005;40:1-19.

2. Murch S, Jenkins H, Auth M, Bremner R, Butt A, France S, et al. Joint BSPGHAN and Coeliac UK guidelines for the diagnosis and management of coeliac disease in children. Arch Dis Child. 2013;98:806-11.

3. Ludvigsson JF, Leffler DA, Bai JC, Biagi F, Fasano A, Green PH, et al. The Oslo definitions for coeliac disease and related terms. Gut. 2013;62:43-52.

4. Oberhüber G, Granditsch G, Vogelsang H. The histopathology of coeliac disease: time for a standardized report scheme for pathologists. Eur J Gastroenterol Hepatol. 1999;11:1185-94

5. National Institute for Health and Care Excellence. Coeliac disease: recognition, assessment and management. NICE guideline (NG20). Published: 2 September 2015. Available from: https://www.nice.org.uk/guidance/ng20

6. ESPGHAN Guidelines for the Diagnosis of Coeliac Disease. J Pediatr Gastroenterol Nutr. 2012;54:136-60.

7. Gujral N, Freeman HJ, Thomson AB. Celiac disease: Prevalence, diagnosis, pathogenesis and treatment. World J Gastroenterol. 2012;18:6036-59.

8. Bardella MT, Fredella C, Saladino V, Trovato C, Cesana BM, Quatrini M, Prampolini L. Gluten intolerance: Gender and age-related differences in symptoms. Scand J Gastroenterol. 2005;40:15-9.

9. Fitzpatrick KP, Sherman PM, Ipp M, Saunders N, Macarthur C. Screening for celiac disease in children with recurrent abdominal pain. J Pediatr Gastroenterol Nutr. 2001;33:250-52.

10. Wessels MM, van Veen II, Vriezinga SL, Putter H, Rings EH, Mearin ML. Complementary serologic investigations in children with celiac disease is unnecessary during follow-up. J Pediatr. 2016;169:55-60.

11. Rajalahti T, Repo M, Kivelä L, Huhtala H, Mäki M, Kaukinen K, et al. Anemia in pediatric celiac disease: association with clinical and histological features and response to gluten-free diet. J Pediatr Gastroenterol Nutr. 2017;64:e1-e6.

12. Howard MR, Turnbull AJ, Morley P, Hollier P, Webb R, Clarke A. A prospective study on the prevalence of undiagnosed coeliac disease in laboratory defined iron and folate deficiency. J Clin Pathol. 2002;55:754-7.

13. Erdem T, Ferat Ç, Nurdan YA, Halime E, Muhammed Selçuk S, Hamza K, Mukadder Ayşe S. Vitamin and mineral deficiency in children newly diagnosed with celiac disease. Turk J Med Sci. 2015;45:833-6.

14. Ahlawat R, Weinstein T, Pettei MJ. Vitamin D in pediatric gastrointestinal disease. Curr Opin Pediatr. 2017;29:122-7.

15. Holmes GK. Coeliac disease and Type 1 diabetes mellitus - the case for screening. Diabet Med. 2001;18:169-77.
16. Larizza D, Calcaterra V, Klersy C, Badulli C, Caramagna C, Ricci A, et al. Common immunogenetic profile in children with multiple autoimmune diseases: the signature of HLA-DQ pleiotropic genes. Autoimmunity. 2012;45:470-5.

17. Bakker SF, Tushuizen ME, Stokvis-Brantsma WH, Aanstoot HJ, Winterdijk P, van Setten PA, et al. Frequent delay of coeliac disease diagnosis in symptomatic patients with type 1 diabetes mellitus: clinical and genetic characteristics. Eur J Intern Med. 2013;24:456-60.

18. Warncke K, Liptay S, Fröhlich-Reiterer E, et al. Vascular risk factors in children, adolescents, and young adults with type 1 diabetes complicated by celiac disease: results from the DPV initiative. Pediatr Diabetes. 2016;17:191-8.

19. Toscano V, Conti FG, Anastasi E, Mariani P, Tiberti C, Poggi M, et al. Importance of gluten in the induction of endocrine autoantibodies and organ dysfunction in adolescent celiac patients. Am J Gastroenterol. 2000;95:1742-8.

20. Kowalska E, Wasowska-Królikowska K, Toporowska-Kowalska E. Estimation of antithyroid antibodies occurrence in children with celiac disease. Med Sci Monit. 2000;6:719-21.

21. Meloni A, Mandas C, Jores RD, Congia M. Prevalence of autoimmune thyroiditis in children with celiac disease and effect of gluten withdrawal. J Pediatr. 2009; 155:51-5.

22. Ansaldo N, Palmas T, Corrias A, Barbato M, D'Altiglia MR, Campanozzi A, et al. Autoimmune thyroid disease and celiac disease in children. J Pediatr Gastroenterol Nutr. 2003;37:63-6.

23. Ozdogan S, Urganci N, Usta M, Kizilkan NU. Prevalence of Asthma and Allergic Rhinitis in Children with Celiac Disease. Iran J Pediatr. 2016;26:e6358.

24. Greco L, De Seta L, D’Adamo G, Baldassarre C, Mayer M, Siani P, Lojodice D. Atopy and coeliac disease: bias or true relation? Acta Paediatr Scand. 1990;79: $670-4$.

25. Kero J, Gissler M, Hemminki E, Isolauri E. Could TH1 and TH2 diseases coexist? Evaluation of asthma incidence in children with coeliac disease, type 1 diabetes, or rheumatoid arthritis: a register study. J Allergy Clin Immunol. 2001;108:781-3.

26. Ress K, Annus T, Putnik U, Luts K, Uibo R, Uibo O. Celiac Disease in Children with Atopic Dermatitis. Pediatr Dermatol. 2014;31:483-8.

27. Ludvigsson JF, Lindelöf B, Zingone F, Ciacci C. Psoriasis in a nationwide cohort study of patients with celiac disease. J Invest Dermatol. 2011;131:2010-6.

28. Andersen AB, Erichsen R, Kappelman MD, Frøslev T, Ehrenstein V. Parental celiac disease and risk of asthma in offspring: a Danish nationwide cohort study. Clin Epidemiol. 2015;7:37-44.

29. Goodwin MS, Cowen MA, Goodwin TC. Malabsorption and cerebral dysfunction: a multivariate and comparative study of autistic children. J Autism Child Schizophr. 1971;1:48-62.

30. Genuis SJ, Bouchard TP. Celiac Disease Presenting as Autism. J Child Neurol. 2010;25:114-9. 
31. Pavone L, Fiumara A, Bottaro G, Mazzone D, Coleman M. Autism and celiac disease: failure to validate the hypothesis that a link might exist. Biol Psychiatry. 1997;42:72-5

32. Batista IC, Gandolfi L, Nobrega YK, Almeida RC, Almeida LM, Campos Junior D, Pratesi R. Autism spectrum disorder and celiac disease: no evidence for a link. Arq Neuropsiquiatr. 2012;70:28-33.

33. Atladottir HO, Pedersen MG, Thorsen P, Mortensen PB, Deleuran B, Eaton WW, Parner ET. Association of family history of autoimmune diseases and autism spectrum disorders. Pediatrics. 2009;124:687-94.

34. Molloy CA, Morrow AL, Meinzen-Derr J, Dawson G, Bernier R, Dunn M, et al. Familial autoimmune thyroid disease as a risk factor for regression in children with autism spectrum disorder: a CPEA study. J Autism Dev Disord. 2006:36:317-24.

35. Comi AM, Zimmerman AW, Frye VH, Law PA, Peeden JN. Familial clustering of autoimmune disorders and evaluation of medical risk factors in autism. J Child Neurol. 1999;14:388-94.

36. Sweeten TL, Bowyer SL, Posey DJ, Halberstadt GM, McDougle CJ. Increased prevalence of familial autoimmunity in probands with pervasive developmental disorders. Pediatrics. 2003;112:e420.

37. Cakir D, Tosun A, Polat M, Celebisoy N, Gokben S, Aydogdu S, et al. Subclinical neurological abnormalities in children with celiac disease receiving a glutenfree diet. J Pediatr Gastroenterol Nutr. 2007;45:366-9.

38. Smith LB, Lynch KF, Kurppa K, Koletzko S, Krischer J, Liu E, et al. Psychological manifestations of celiac disease autoimmunity in young children. Pediatrics. 2017;139(3):pii: e20162848

39. Hadjivassiliou M, Grünewald RA, Lawden M, Davies-Jones GA, Powell T, Smith CM. Headache and CNS white matter abnormalities associated with gluten sensitivity. Neurology. 2001;56:385-8.

40. Pynnönen PA, Isometsä ET, Verkasalo MA, et al. Glutenfree diet may alleviate depressive and behavioural symptoms in adolescents with coeliac disease: a prospective followup caseseries study. BMC Psychiatry. 2005;5:14.

41. Işıkay S, Kocamaz H2, Sezer S2, Özkars MY2, Işıkay N2, Filik B, et al. The frequency of epileptiform discharges in celiac disease. Pediatr Neurol. 2015;53:78-82.

42. Bonamico M, Mariani P, Danesi HM, Crisogianni M, Failla P, Gemme G, et al. Prevalence and clinical picture of celiac disease in Italian Down syndrome patients: a multicenter study. J Ped Gastroenterol Nutr. 2001;33:139-43.

43. Book L, Hart A, Black J, Feolo M, Zone JJ, Neuhausen SL. Prevalence and clinical characteristics of celiac disease in Down syndrome in a U.S. study. Am J Med Genet. 2001;98:70-4

44. Csizmadia CG, Mearin ML, Oren A, Kromhout A, Crusius JB, von Blomberg $\mathrm{BM}$, et al. Accuracy and cost-effectiveness of a new strategy to screen for celiac disease in children with Down syndrome. J Pediatr. 2000;137:756-61.

45. Kolek A, Vospelová J, Hermanová Z, Santavá A, Tichý M. Occurrence of coeliac disease in children with Down's syndrome in north Moravia, Czech Republic. Eur J Pediatr. 2003;162:207-8.

46. Rostom A, Murray JA, Kagnoff MF. American Gastroenterological Association (AGA) Institute technical review on the diagnosis and management of celiac disease. Gastroenterology. 2006;131:1981-2002.

47. Giannotti A, Tiberio G, Castro M, Virgilii F, Colistro F, Ferretti F, et al. Coeliac disease in Williams syndrome. J Med Genet. 2001;38:767-8

48. Online Mendelian Inheritance in Man, OMIM ${ }^{\circledR}$. Johns Hopkins University, Baltimore, MD. MIM Number: 212750, Last edited: 4/8/2015. World Wide Web URL: https://omim.org/

49. Romani M, Micalizzi A, Valente EM. Joubert syndrome: congenital cerebellar ataxia with the molar tooth. Lancet Neurol. 2013;12:894-905

50. Hadjivassiliou M, Grünewald RA, Chattopadhyay AK, et al. Clinical, radiological, neurophysiological, and neuropathological characteristics of gluten ataxia. Lancet. 1998;352:1582-5.

51. Hadjivassiliou M, Mäki M, Sanders DS, Williamson CA, Grünewald RA, Woodroofe NM, et al. Autoantibody targeting of brain and intestinal transglutaminase in gluten ataxia. Neurology. 2006;66:373-7.

52. Ooi CY, Day AS, Jackson R, Bohane TD, Tobias V, Lemberg DA. Eosinophilic esophagitis in children with celiac disease. J Gastroenterol Hepatol. 2008;23:1144-8.

53. Dharmaraj R, Hagglund K, Lyons H. Eosinophilic esophagitis associated with celiac disease in children. BMC Res Notes. 2015;8:263.

54. Hommeida S, Alsawas M, Murad MH, Katzka DA, Grothe RM, Absah I The association between Celiac Disease and Eosinophilic Esophagitis: Mayo Experience and Meta-analysis of the Literature. J Pediatr Gastroenterol Nutr. 2017:65:58-63.

55. Leslie C, Mews C, Charles A, Ravikumara M. Celiac disease and eosinophilic esophagitis: a true association. J Pediatr Gastroenterol Nutr. 2010;50:397-9.

56. Lucendo AJ, Arias Á, Tenias JM. Systematic review: the association between eosinophilic oesophagitis and coeliac disease. Aliment Pharmacol Ther. 2014;40:422-34.

57. Pascual V, Dieli-Crimi R, López-Palacios N, Bodas A, Medrano LM, Núñez C. Inflammatory bowel disease and celiac disease: Overlaps and differences. World J Gastroenterol. 2014;20:4846-56.

58. Kocsis D, Tóth Z, Csontos ÁA, Miheller P, Pák P, Herszényi L, et al. Prevalence of inflammatory bowel disease among coeliac disease patients in a Hungarian coeliac centre. BMC Gastroenterol. 2015;15:141
59. Tursi A, Giorgetti GM, Brandimarte G, Elisei W. High prevalence of celiac disease among patients affected by Crohn's disease. Inflamm Bowel Dis. 2005;11:662-6.

60. Yang A, Chen Y, Scherl E, Neugut AI, Bhagat G, Green PH. Inflammatory bowel disease in patients with celiac disease. Inflamm Bowel Dis. 2005;11:528-32.

61. Virta LJ, Kolho KL. The risk of contracting pediatric inflammatory bowel disease in children with celiac disease, epilepsy, juvenile arthritis and type 1 diabetes - a nationwide study. J Crohns Colitis. 2013;7:53-7.

62. El-Matary W, Senthilselvan A, Fedorak RN, Dieleman L, Spady D. Celiac disease in children with inflammatory bowel disease: a prospective cohort study. Am J Gastroenterol. 2013;108:455-6.

63. Danese C, Castori M, Celletti C, Amato S, Lo Russo C, Grammatico P, Camerota F. Screening for celiac disease in the joint hypermobility syndrome/Ehlers-Danlos syndrome hypermobility type. Am J Med Genet Part A. 2011;155:2314-6.

64. Fikree A, Aktar R, Grahame R, Hakim AJ, Morris JK, Knowles CH, Aziz Q. Functional gastrointestinal disorders are associated with the joint hypermobility syndrome in secondary care: a case-control study. J Neurogastroenterol Motil. 2015;27:569-79.

65. Laszkowska M, Roy A, Lebwohl B, Green PH, Sundelin HE, Ludvigsson JF. Nationwide population-based cohort study of celiac disease and risk of Ehlers-Danlos syndrome and joint hypermobility syndrome. Dig Liver Dis. 2016;48:1030-4.

66. Collin P, Reunala T, Pukkala E, Laippala P, Keyriläinen O, Pasternack A. Coeliac disease associated disorders and survival. Gut. 1994;35:1215-8.

67. Rodrigo L, Pérez-Martinez I. Osteogenesis Imperfecta with Celiac Disease and Type II Diabetes Mellitus Associated: Improvement with a Gluten-Free Diet. Case Rep Med. 2012;2012:813461

68. Iqbal T, Zaidi MA, Wells GA, Karsh J. Celiac disease arthropathy and autoimmunity study. J Gastroenterol Hepatol. 2013;28:99-105.

69. Lubrano E, Ciacci C, Ames PR, Mazzacca G, Oriente P, Scarpa R. The arthritis of celiac disease: prevalence and pattern in 200 adult patients. Br J Rheumatol. 1996;35:1314-8.

70. Lerner A, Matthias T. Rheumatoid arthritis-celiac disease relationship: joints get that gut feeling. Autoimmun Rev. 2015;14:1038-47.

71. Atteno M, Costa L, Cozzolino A, Tortora R, Caso F, Del Puente A, et al. The enthesopathy of celiac patients: effects of gluten-free diet. Clin Rheumatol. 2014:33:537-41.

72. Atteno M, Costa L, Tortora R, Cozzolino A, Del Puente A, Caso F, et al. The occurrence of lower limb enthesopathy in coeliac disease patients without clinical signs of articular involvement. Rheumatology (Oxford). 2013;52:893-97.

73. Peluso R, Di Minno MN, Iervolino S, Manguso F, Tramontano G, Ambrosino $\mathrm{P}$, et al. Enteropathic spondyloarthritis: from diagnosis to treatment. Clin Dev Immunol. 2013;2013:631408.

74. Espinosa M, Gottlieb BS. Juvenile Idiopathic Arthritis. Pediatr Rev. 2012;33: 303-13.

75. Lepore L, Martelossi S, Pennesi M, Falcini F, Ermini ML, Ferrari R, et al. Prevalence of celiac disease in patients with juvenile chronic arthritis. J Pediatr. 1996;129:311-3

76. Stagi S, Giani T, Simonini G, Falcini F. Thyroid function, autoimmune thyroiditis and coeliac disease in juvenile idiopathic arthritis. Rheumatology (Oxford). 2005:44:517-20

77. Wierink CD, van Diermen DE, Aartman IH, Heymans HS. Dental enamel defects in children with coeliac disease. Int J Paediatr Dent. 2007;17:163-8.

78. de Carvalho FK, de Queiroz AM, Bezerra da Silva RA, Sawamura R, Bachmann L, Bezerra da Silva LA, Nelson-Filho P. Oral aspects in celiac disease children: clinical and dental enamel chemical evaluation. Oral Surg Oral Med Oral Pathol Oral Radiol. 2015;119:636-43.

79. Herwis K, Elturki H, Ali A. Prevalence of dental findings of children with celiac disease in Libya: a comparative study. Case Rep Clin Pathol. 2015;2:61-6.

80. El-Hodhod MA, El-Agouza IA, Abdel-Al H, Kabil NS, Bayomi KA. Screening for celiac disease in children with dental enamel defects. ISRN Pediatr. 2012; 2012:763783

81. Kotze LMS. Dermatitis Herpetiformis, the celiac disease of the skin! Arq Gastroenterol. 2013;50:231-5.

82. Caproni M, Bonciolini V, D'Errico A, Antiga E, Fabbri P. Celiac Disease and Dermatologic Manifestations: Many Skin Clue to Unfold Gluten-Sensitive Enteropathy. Gastroenterol Res Pract. 2012;2012:952753.

83. Abenavoli L, Proietti I, Leggio L, Ferrulli A, Vonghia L, Capizzi R, et al. Cutaneous manifestations in celiac disease. World J Gastroenterol. 2006;12:843-52.

84. Ludvigsson JF, Hemminki K, Wahlström J, Almqvist C. Celiac disease confers a 1.6-fold increased risk of asthma: A nationwide population-based cohort study. J Allergy Clin Immunol. 2011;127:1071-3.

85. Ojetti V, Aguilar Sanchez J, Guerriero C, Fossati B, Capizzi R, De Simone C, et al. High prevalence of celiac disease in psoriasis. Am J Gastroenterol. 2003;98:2574-5.

86. Durand JM, Lefevre P, Weller C. Erythema nodosum and celiac disease. Br J Dermatol. 1991;125:291-2

87. Bartyik K, Várkonyi A, Kirschner A, Endreffy E, Túri S, Karg E. Erythema nodosum in association with celiac disease. Pediatr Dermatol. 2004:21:227-30. 